\title{
13: $32058624-32250157$
}

National Cancer Institute

\section{Source}

National Cancer Institute. 13: 32058624-32250157. NCI Thesaurus. Code C41706.

Physical location of APRIN_Gene 